\title{
A Socialist Price System: Answering the Austrians
}

\author{
David McMullen \\ Melbourne, Australia \\ dfmcmullen@gmail.com \\ https://orcid.org/0000-0001-6148-0720
}

March 6, 2022

\begin{abstract}
According to economists of the Austrian school, even with everyone's best efforts, a system based on social ownership of the means of production could not effectively deploy a decentralized price system. The case is made primarily by Mises and Hayek in the 1920s and 1930s with a further contribution by Lavoie in the 1980s. Their argument can be broken down into two elements. Firstly, only the competitive market process can give prices the coordinative meaning necessary for economic calculation. Secondly, we cannot do without capitalists. To begin with, there has to be people with "skin in the game"; and, furthermore, those running socialist firms would not be in a position to replace the capitalists in the entrepreneurial role that the latter perform in an ever-changing economy. An examination of the key writings on these questions by these three economists reveals that their case rests on very shaky ground. The case is weakened further when one looks at the ways in which a socialist price system could be an improvement on what capitalism offers. The article also discusses the Lange and Dickinson 'neoclassical' models and shows them to be irrelevant diversions.
\end{abstract}

keywords: socialist calculation debate; Austrian economics; von Mises; Hayek; socialism; economic calculation JEL Codes: B13; B24, B53; P22

Economists of the Austrian School believe they have shown that an economic system based on social ownership of the means of production would inevitably have an insurmountable problem with economic calculation, and this would leave it groping in the dark and unable to direct scarce resources to their most valuable use. They contend that this problem would exist even if people were motivated to do their best. The emergence of the new person for the new society would not suffice. According to one of the School's leading contemporary members: '... it must rank among the fundamental contributions to economic science in the twentieth century.' (Boettke 2000, p. 13)

This position is particularly convenient because it allows you to dismiss social ownership without having to get into interminable and inconclusive arguments about whether it is against human nature. Furthermore, excuses for the 'failure of communism' such as capitalist encirclement, the backwardness of the countries concerned, major political errors or the victory of capitalist roaders become irrelevant. It could never have succeeded. The political malaise was ultimately due to this underlying economic impossibility problem.

The calculation debate began in 1920 when Ludwig von Mises, the most prominent figure in the Austrian pantheon, challenged claims by proponents of social ownership that market prices could be superseded by calculation in kind or in labor units (Mises [1920] 1935). This was followed by another debate on whether a system based on social ownership could instead have its own decentralized price system. The first debate is still slowly smoldering away, but will not be 
touched on here. (See Cockshott and Cottrell 1993a and 1993b; Horwitz 1996.) This article will be confined to challenging the Austrian position in the second contest. In doing this, the aim is not to propose how prices ought to be used in a socialist system but simply to argue that there is no 'calculation problem' limiting how they could be used. Apart from those of Lavoie (1984, 1986 and 1990), contributions on socialist calculation by Austrian economists other than Mises and Hayek are not relevant to the question at hand, or add nothing new, and need not be referred to here.

Throughout the article there will be constant references to 'socialist angels'. This may be annoying but it will remind the reader that the calculation problem, if it exists, is impervious to the best of human endeavors; and if something is a problem only in the absence of socialist angels then we have moved beyond the calculation debate into the realm of motivation and behavior. The words 'socialism' and 'socialist' are used here interchangeably with social ownership even though they are now more often than not used to refer to government ownership and intervention in a capitalist society.

Mises and his most famous student, the future Nobel laureate Friedrich Hayek, had become aware of proposals for what they referred to variously as 'artificial markets' (Mises [1922] 1981, p. 137), 'quasi-markets' (Mises [1949] 1998, p. 701) and 'pseudo competition' (Hayek 1935, p. 237). Hayek described them as follows:

Although it is not yet possible to refer to published work on these lines, what one has learnt about them in conversations and discussions is probably sufficient to make worth while some examination of their content.

In many respects these plans are very interesting. The common fundamental idea is that there should be markets and competition between independent entrepreneurs or managers of individual firms, and that in consequence there should be money prices, as in the present society, for all goods, intermediate or finished, but that these entrepreneurs should not be owners of the means of production used by them but salaried officials of the State, acting under State instructions and producing, not for profit, but so as to be able to sell at prices which will just cover costs (Hayek 1935, p. 218).

The Austrian contention is that the price mechanism cannot do without two things that are necessarily absent from social ownership, namely, markets for means of production and capitalists. After addressing these two claims, our attention will turn to the critique by Hayek of the 'neoclassical socialists'. This is worth discussing because it is a strawman that invariably pops up when Austrian economists discuss the calculation question. Finally, some space is devoted to speculating on how socialist angels could create a better price system than the one we have under capitalism.

\section{Do We Need Markets for Means of Production?}

By the very nature of social ownership, a socialist economy could not have market exchanges between firms, if by market exchange we mean the transfer of ownership. Instead, a decentralized price system in such an economy would have to entail the exchange of custody over what would always remain socially owned. Intermediate inputs would start out in the custody of firms that produce them. Then for production to proceed their custody would be transferred to user firms and the transaction would occur through a decentralized purchasing 
process where these firms would spend either revenue from past transactions, lines of credit or funds provided for investment.

In his first piece on the calculation theme, Mises denies the very notion that exchanges between firms could be ones of custody rather than of ownership but provides no reason for holding this view. Here he wrote:

We might conceive of a situation, in which exchange between particular branches of business is permitted, so as to obtain the mechanism of exchange relations (prices) and thus create a basis for economic calculation even in the socialist commonwealth. Within the framework of a uniform economy knowing not private ownership of the means of production, individual labour groups are constituted independent and authoritative disposers, which have indeed to behave in accordance with the directions of the supreme economic council, but which nevertheless assign each other material goods and services only against a payment, which would have to be made in the general medium of exchange. It is roughly in this way that we conceive of the organization of the socialist running of business when we nowadays talk of complete socialization and the like. But we have still not come to the crucial point. Exchange relations between production-goods can only be established on the basis of private ownership of the means of production. When the 'coal syndicate ' provides the 'iron syndicate' with coal, no price can be formed, except when both syndicates are the owners of the means of production employed in their business. This would not be socialization but workers' capitalism and syndicalism. (Mises [1920] 1936, pp. 111-112)

When he comes to what he refers to as 'artificial market' proposals, he presumes that the proponents are intending to retain markets but have forgotten that markets are impossible without private owners seeking gain.

Unfortunately the supporters of such proposals do not see (or perhaps will not see) that it is not possible to divorce the market and its functions in regard to the formation of prices from the working of a society which is based on private property in the means of production and in which, subject to the rules of such a society, the landlords, capitalists and entrepreneurs can dispose of their property as they think fit. For the motive force of the whole process which gives rise to market prices for the factors of production is the ceaseless search on the part of the capitalists and the entrepreneurs to maximize their profits by serving the consumers' wishes. Without the striving of the entrepreneurs (including the shareholders) for profit, of the landlords for rent, of the capitalists for interest and the labourers for wages, the successful functioning of the whole mechanism is not to be thought of. It is only the prospect of profit which directs production into those channels in which the demands of the consumer are best satisfied at least cost. If the prospect of profit disappears the mechanism of the market loses its mainspring, for it is only this prospect which sets it in motion and maintains it in operation. The market is thus the focal point of the capitalist order of society; it is the essence of Capitalism. Only under Capitalism, therefore, is it possible; it cannot be 'artificially' imitated under Socialism. (Mises [1936] 1951, pp. 137-138)

All this simply muddies the waters. What matters is whether a price system based on the exchange of custody could match (or even surpass) one based on exchange of ownership. This 
question was explicitly addressed by the Austrian economist Don Lavoie many years later. According to Lavoie:

[I]t is only through the rivalrous bidding of independent owners of the means of production that prices tend to have the coordinative 'meaning' necessary for their function in economic calculation. (Lavoie 1985, p. 181)

And elsewhere in a similar vein we read:

It is precisely through rivalrous contention by separate and independent owners that market participants are able to impart information to the prices of factors of production, prices that in turn allow them to intelligently appraise alternative avenues of production. Producers' good prices are not 'derived' logically from consumers' goods prices, they are 'imputed' through a historical process of competition. (Lavoie 1986, p. 8)

Lavoie insists that this is a calculation problem rather than a motivation one:

This does not, however, reduce to the mere question of 'incentives' in the narrow sense of psychological motivation. The 'incentives' of the profit and loss system do not merely motivate action; they inform it. (Lavoie 1985, p. 177)

And some years later he says:

Profit in this view is not so much an inducement to effort as a signal about where opportunities lie. The role of profits is not primarily to motivate people to do the right thing but to find out, through the process of interplay itself, what the right thing to do might be. (Lavoie 1990, p. 78)

The contention is that socialist angels would not be able to deploy a decentralized price system to equal effect. However, this is not at all obvious. There is no difficulty in imagining numerous firms in each sector, all trying their own way of doing things and bidding for resources, with consumer demand ultimately driving it all. There may be tensions between rivalry and cooperation that could cause challenges for socialist angels but not disastrous consequences.

Socialist angels who by their nature cooperate fully with others would have to resist the temptation to hold back in their dealings with rivals even when it might cause some personal disadvantage. This would be the case where their openness or assistance leads to a rival coming up with something better and cheaper, and as a result their own efforts come to nothing. This would of course be a rather disagreeable experience. (By the way, we should keep in mind that we are in a world where material gain does not motivate people's actions, so it is not there to provide an incentive to be underhanded.)

Cooperation could also be undermined if there is too much reliance on the bottom line. For example, if a firm came up with a way of reducing costs, a product improvement or a selling opportunity, cooperation would require it to tell other firms about it, while maximizing profits would require it to keep it under wraps. However, this would only be a serious problem if there were some great difficulty in ensuring that firms were not disadvantaged or marked down for being cooperative. Good reports from other firms that benefited from their cooperative behavior could be part of the answer. 


\section{Do We Need Capitalists?}

Mises and Hayek contend that the 'competitive' solution could not handle the important business decisions and as a result these would have to stay with some central authority. It is all very well to have enterprises trading with each other in order to provide consumers with what they want. However, the immediate provision to consumers is only part of the story and the least important from a calculation point of view. You also have to consider adjustment for change and growth, and this includes production for investment.

In Socialism, we read:

The problem of economic calculation is a problem which arises in an economy which is perpetually subject to change, an economy which every day is confronted with new problems which have to be solved. Now in order to solve such problems it is above all necessary that capital should be withdrawn from particular lines of production, from particular undertakings and concerns and should be applied in other lines of production, in other undertakings and concerns. This is not a matter for the managers of joint stock companies, it is essentially a matter for the capitalists - the capitalists who buy and sell stocks and shares, who make loans and recover them, who make deposits in the banks and draw them out of the banks again, who speculate in all kinds of commodities. (Mises [1936] 1951, p.139)

In Human Action he makes a similar point:

The market of the capitalist society also performs all those operations which allocate the capital goods to the various branches of industry. The entrepreneurs and capitalists establish corporations and other firms, enlarge or reduce their size, dissolve them or merge them with other enterprises; they buy and sell the shares and bonds of already existing and of new corporations; they grant, withdraw, and recover credits; in short they perform all those acts the totality of which is called the capital and money market. It is these financial transactions of promoters and speculators that direct production into those channels in which it satisfies the most urgent wants of the consumers in the best possible way. These transactions constitute the market as such. If one eliminates them, one does not preserve any part of the market. What remains is a fragment that cannot exist alone and cannot function as a market. (Mises [1949] 1998, p. 704)

When they get to specifics, they share two concerns. The first relates to risk and the fact that people would not have 'skin in the game'. The second is the view that the big business decisions are beyond the purview of the basic economic units which such a system would comprise. We will now look at the risk and purview questions in turn.

\section{No Skin in the Game}

Mises and Hayek argue that the 'director' at the center would have to keep hold of the reins because people could not be trusted with investment funds. So, the central authority could not simply act as a banker providing funds to units that promise the best returns because, unlike capitalists, they are not putting up money of their own. 
According to Mises:

All those who can bid for these funds have, as is self evident in a socialist order of society, no property of their own. In bidding they are not restrained by any financial dangers they themselves run in promising too high a rate of interest for the funds borrowed. (Mises [1949] 1998, p. 705)

And then according to Hayek:

It is not possible to conceive of this central authority simply as a kind of super-bank which lends the available funds to the highest bidder. It would lend to persons who have no property of their own. (Hayek 1935, pp. 232-234)

Mises and Hayek, however, have different views of the problem.

According to Mises in Socialism:

... [S] uch a state of affairs would simply mean that those managers who were less cautious and more optimistic would receive capital to enlarge their undertakings while more cautious and more sceptical managers would go away empty-handed. (Mises [1936] 1951, p. 140)

And in Human Action we read:

If the director were without hesitation to allocate the funds available to those who bid most, he would simply put a premium upon audacity, carelessness, and unreasonable optimism. He would abdicate in favor of the least scrupulous visionaries or scoundrels. (Mises [1949] 1998, p. 705).

You could certainly imagine some socialist angels being more discerning and astute than others. However, we would need a reason to believe that this would have a disastrous impact, indeed so disastrous that it would be necessary for the 'director' to retain control. Furthermore, what Mises says in Human Action, moves well outside of the calculation debate into the realm of motivation and behavior. We are no longer dealing with the differing foibles and aptitude of socialist angels but the behavior of unscrupulous scoundrels.

Hayek sees the problem in a different way:

The decision to whom to entrust a given amount of resources will have to be made on the basis of individual promises of future return. ... The central authority will have no other grounds on which to decide but the past performance of the entrepreneur. But how are they to decide whether the risks he has run in the past were justified? ....

[E]ven the best entrepreneur will occasionally make losses and sometimes even very heavy losses. Is he to be blamed if his capital has become obsolete because of an invention or a change in demand? How is it to be decided whether he was entitled to take a certain risk? Is the man who never makes losses because he never takes a risk 
necessarily the man who acts most in the interest of the community? There will certainly be a tendency to prefer the safe to the risky enterprise.

But risky and even the purely speculative undertakings will be no less important here as under capitalism. ... How long is a formerly successful entrepreneur to be suffered to go on making losses? If the penalty for loss is the surrender of the position of 'entrepreneur' will it not be almost inevitable that the possible chance of making a loss will operate as so strong a deterrent that it will outbalance the chance of the greatest profit? Under capitalism, too, loss of capital may mean loss of status as capitalist. But against this deterrent is always the attraction of the possible gain. Under socialism this cannot exist. (Hayek 1935, pp.234-5)

What Hayek is saying is that capitalists take risks knowing that there is the prospect of a considerable profit and as long as they do not put all their eggs in one basket, they can survive losses until the next big win. The market is the judge. They do not have bureaucrats looking over their shoulder who they have to second guess.

Hayek's reasoning seems more compelling than that of Mises, given that we are looking at ongoing behavior rather than a one-off event. And one can imagine there would be a limit to the extent that even socialist angels would be prepared to endure being blamed for blunders that were not their fault, and as a result would play it safe. If this were a problem, it would indeed mean reduced performance but would it really be an economy operating in the dark and doomed to stagnation? Would it be enough of a problem to make central direction of investment necessary? In both the Mises and Hayek versions of the problem, their extent would depend on how well proposals were scrutinized. There would be people in the funding agencies, the industry sector and the firm itself who would have the knowledge and skills to filter out at least some of the ill considered ones. Likewise, there would be people who could keep an eye on approved projects and reach informed views on why a project was over budget, behind schedule or failing to make a good return once completed. They would then be in a better position to assess whether those who put up the proposal should have anticipated these problems.

Whether the attitude of the typical socialist angel to risk would be better or worse than that of capitalists and their highly paid subordinates is not something we can delve into here. However, it is safe to say that the former would seriously assess the prospects of a proposal and, where they felt the risk was high, to only propose or approve it where the upside appeared particularly good. Hence, any problems in this area would be a rather thin basis on which to rest a calculation case against social ownership.

\section{Narrow Purview of the Firm}

As well as seeing a problem of unreliability in the face of risk and uncertainty, Mises and Hayek also contend that the more dynamic business decisions are not in the purview of the firm and therefore would have to be assigned to the center.

Mises questions the competence of those who would be running firms to deal with the bigger entrepreneurial questions. He contends that if they are like managers of capitalist firms they would be narrowly focused on their own operations. In Socialism he says: 
Under Capitalism, the capitalist decides to whom he will entrust his own capital. The beliefs of the managers of joint stock companies regarding the future prospects of their undertakings and the hopes of project-makers regarding the profitability of their plans are not in any way decisive. The mechanism of the money market and the capital market decides. This indeed is its main task: to serve the economic system as a whole, to judge the profitability of alternative openings and not blindly to follow what the managers of particular concerns, limited by the narrow horizon of their own undertakings, are tempted to propose. (Mises [1936] 1951, p. 140)

And then in Human Action we read:

Our problem does not refer to the managerial activities; it concerns the allocation of capital to the various branches of industry. The question is: In which branches should production be increased or restricted, in which branches should the objective of production be altered, what new branches should be inaugurated? With regard to these issues it is vain to cite the honest corporation manager and his well-tried efficiency. Those who confuse entrepreneurship and management close their eyes to the economic problem. (Mises [1949] 1998, p. 704).

Mises greatly understates the role of the people who run capitalist firms. You will find that they tend to focus on the more strategic issues while having others concentrate on day-to-day production matters. They decide to expand and contract activities, and negotiate mergers. They also found and run startups. There is no reason why socialist angels could not do the same. They may of course, just as firms do now, call in outside advisers or partners to assist with anything about a new project that is not sufficiently familiar to people on staff.

Certainly, as is presently the case, they would depend on people outside agreeing to fund their proposals. The latter would need to be convinced that these had sufficiently good prospects of high returns; and in the course of their assessment, they may well draw on a broader perspective than that of the applicant. But even here are we necessarily dealing with some central Leviathan? External funding decisions would not have to be highly centralized.

You would expect that a central authority would be ultimately responsible for funding all investment. As the one and only 'stockholder', you could imagine it receiving all net revenue from the firms and then redistributing it to investment projects. However, there is nothing about social ownership that rules out a very hands-off approach. For example, there may be a central policy on what share different sectors are to receive, or decisions may be entirely left to funding agency personnel to make the decision.

The system could also be highly decentralized by introducing numerous funding agencies staffed by people with informed views on where investment funds should go. This would deal with Lavoie's concern about diversity of approaches as applicants could knock on a number of doors. The center would, of course, need a process for determining how funds are distributed among the agencies. For example, financial success of the existing portfolio would be a simple rule and very hands-off; or a more hands-on approach would devote some effort to looking beneath the raw numbers. 
Hayek contends that units could not be left to make investment decisions because they affect the structure of the industry:

The decision about the amount of capital to be given to an individual entrepreneur and the decision thereby involved concerning the size of the individual firm under a single control are in effect decisions about the most appropriate combination of resources. It will rest with the central authority to decide whether one plant located at one place should expand rather than another plant situated elsewhere. All this involves planning on the part of the central authority on much the same scale as if it were actually running the enterprise. (Hayek 1935, pp. 236-7)

This is an odd view. If capitalist firms can manage to invest autonomously why couldn't economic units under social ownership? He also cites a book on industry structure he believes bolsters his case:

For a more detailed discussion of how the size of the individual firm is determined under competition and of the way in which this affects the appropriateness of different methods of production and the costs of the product, cf. [(Robinson, 1931)]. (Hayek 1935, p. 236)

Unfortunately, with libraries closed for the pandemic the author was not able to obtain a copy; however, according to one review of the book it examines what determines the optimum size for firms and operations, in other words the size that will deliver the least cost per unit of output (Florence, 1932). In particular, Robinson discusses the effect of economies of scale in technology, management, finance, marketing and coping with risk. Hayek does not explain why socialist firms could not get together whenever necessary with other firms in their own and related industries to redraw boundaries. You could imagine them merging or shifting operations from one to another in order to achieve the most economical level of vertical integration and scale.

Hayek also contends that 'pseudo competition' would have a problem deciding whether a going concern is making the best use of resources and whether they should be transferred elsewhere. As he points out, resources constantly shift between firms under capitalism and this would be equally advantageous in a socialist state. He asks:

What is to be the decision if another entrepreneur promises to get a higher return out of the plant (or even an individual machine) than that on which the present user bases his valuation? Is the plant or machine to be taken from him and to be given to the other man in his mere promise? (Hayek 1935, p. 235)

Hayek reminds us that under capitalism the firms that are more profitable pull resources away from the less profitable and this is made possible by their right to retain and deploy their profits. In this way resources automatically shift to those who would make best use of them. He asks whether socialist firms would be allowed to retain profits and use them for this purpose.

In a capitalist firm owned by individuals, they can choose to plough back profits, invest them elsewhere or consume them. In a joint stock company, some profit may be retained with the rest 
going to stockholders. How much is retained is a financial balancing act. It needs to avoid deterring investors by offering the advantages of more equity and higher dividends in the future.

If there is to be scope for profit retention where the socialist state is the only stockholder, there would have to be some other arrangement. What that could be cannot be determined here. However, there are two things that would reduce its importance: firstly, quick and simple approval processes for funding of small scale increases in capacity; and secondly, widespread use of leasing for premises and moveable equipment where the regular payments would be covered by the increased revenue. As for the firms in present possession of the assets, one could readily imagine them selling equipment or terminating leases if this improved their bottom line.

\section{Hayek's Retreat}

It is interesting that Hayek acknowledges that the calculation problem is not immediately obvious:

At first sight it is not evident why such a socialist system with competition within industries as well as between them should not work as well or as badly as competitive capitalism. All the difficulties one might expect to arise seem likely to be only of that psychological or moral character about which so little definite can be said. (Hayek 1935, p. 232).

Furthermore, his conclusion is not the crisp and clear claim that economic calculation is logically impossible. Rather, he sees a serious but uncertain level of impracticality and underperformance:

It must again be pointed out here that general considerations of the kind which can be advanced in a short essay can lead to no decisive conclusions. Only by intensive application of analysis on these lines to the phenomena of the real world is it possible to arrive at approximate estimates of the quantitive importance of the phenomena which have been discussed here. (Hayek 1935, p. 240).

Logical impossibility does not require empirical investigation and can indeed lead to decisive conclusions. This is clearly a retreat by Hayek from what is supposed to be the great Austrian contribution to comparative economics.

\section{The Neoclassical Socialists}

An important part of the calculation debate were the economic models or proposals presented by the neoclassical socialists, particularly Lange (1937) and Dickinson (1939), and then the subsequent rebuttal in Hayek (1940).

The former endeavor to show that their models are comparable to the static equilibrium model of neoclassical economics where prices are determined by the trial-and-error process of Walras' auctioneer and are given to producers as 'parameters' rather than things for them to determine. However, instead of the auctioneer they have a pricing body that looks at inventories. Prices are raised if inventories are low and brought down if high. Hayek was quick to point out that such a model is not applicable to the real world and does not provide a proper price system. 
In a decentralized price system, prices are not simply parameters given to firms. Instead, firms bid inputs away from other less valued uses and offer their output at prices that undercut more costly alternatives. Waiting for central inventory-guided adjustment in the case of excess demand would mean a mad scramble with first in best dressed and no ability of producers to increase supply by bidding inputs away from other uses. In the case of a new low-cost producer, there would be no ability to take business away from a high cost producer by undercutting them. Presumably, they would first have to create a glut that is noticed by the adjustment agency.

Apart from this fundamental limitation of parametric pricing, there are also practical problems to consider. Firstly, some goods and services are one-offs:

Wherever we have a market for a fairly standardized commodity, it is at least conceivable that all prices should be decreed in advance from above for a certain period. The situation is, however, very different with respect to commodities which cannot be standardized, and particularly for those which today are produced on individual orders, perhaps after invitation for tenders. A large part of the product of the 'heavy industries,' which, of course, would be the first to be socialized, belongs to this category. Much machinery, most buildings and ships, and many parts of other products are hardly ever produced for a market, but only on special contract. (Hayek 1940, pp. 188-89)

Also, most goods can be broken down into 100s or 1000s of varieties often with different costs and there is a constant flow of new goods or varieties of existing ones. Even identical goods differ in terms of required time of delivery and this can affect the cost. If pricing were not left to those closely involved, there would be excessive lumping together of items and untimely price adjustment.

Because of the prevailing neoclassical mental straight jacket, economists as a whole considered that Lange had answered Mises and won the debate (Boettke 2000, p. 15). The Austrians understandably felt aggrieved by this. However, being correct in claiming that these models do not have a proper decentralized price system does nothing to further the argument that socialism could not have such a system. Nevertheless, this has not stopped contemporary Austrian economists from turning them into a strawman and deeming them to be the case for a socialist price system. Boettke (2000) is an example of this.

\section{A Better Price System}

If there are no obstacles to socialist angels developing a quite satisfactory price system, it is no longer out of court to speculate on ways in which they could do a better job than capitalists. Once again, it is worth reminding the reader that we are assuming there are no motivation/behavior problems sabotaging socialism. If we go there, we are moving outside the calculation debate. Below are listed some of the more important improvements that we could expect to see.

1. The first that comes to mind is the treatment of the external costs that do not show up in the accounts of capitalist firms. For example, firms under social ownership could come together to decide on how to deal with the environmental costs of their operations. You could imagine them 
doing a better job than that presently performed by outside bureaucrats trying to deal with 'market failure'.

2. At the same time there would not be the problem of 'government failure'. The Public Choice literature has done a compelling job of showing how capitalist governments are thoroughly corrupt and cater to people who want the government to enhance the value of their capital by measures such as subsidies and protection from competition.

3. Then there is the beneficial effect on prices of greater transparency. As mentioned above, firms would share information about reducing costs and temporary shortages. This would lead to more rapid costs reductions and price adjustments than under capitalism where this information only slowly leaks out, and in the meantime the firm with the information limits supply and maximizes profits.

4. Another way that the price system under socialism could be superior is if it is able to avoid crises and business cycles. Hayek says that the 'competitive solution' would be expected to have crises just like capitalism and so would lose one of the claimed advantages of socialism. He concludes as follows:

But there is no reason why a competitive socialist system should be in a better position to avoid Crises and unemployment than competitive capitalism. Perhaps an intelligent monetary policy may reduce their severity for both, but there are no possibilities in this respect under competitive socialism which would not equally exist under capitalism. (Hayek 1935, p. 240)

This is no place to make pronouncements on the causes and cures of economic crises, however, one can observe that the system being discussed lacks some of the features people often associate with such phenomena.

To begin with, aggregate demand is assured. The government can always spend the net revenue they receive from firms and the taxation they receive from individuals. There could be a problem if the savings of the latter are not matched by consumer borrowing and deposit drawdowns. However, if people stubbornly refuse to increase their consumption, despite low interest rates, the government could either borrow some of these funds or increase taxation.

The usual sources of financial instability are absent. A government's debt would be limited to temporary balance of payments deficits with other countries and any aforementioned borrowing from individuals' savings. The funds it provides for investment would be the net revenue it receives from firms, they would not be borrowed from anybody. These funds could be provided to firms as grants, or if they were loans they could be easily forgiven or rescheduled because the funding agencies are not financial intermediaries with debts of their own.

Finally, the Austrian theory of the business cycle would not apply here. It is a credit theory of crisis that blames fractional reserve banking made worse by loose government monetary policy (Batemarco, 1994). A boom is set off by the resulting low interest rates that encourage more longer-term investments unmatched by the necessary freeing up of resources by reduced consumption (and so increased savings). This comes home to roost as a crisis when not all the 
investment plans can be profitably completed. However, under the system we are discussing, there would be a match between saving and investing because they are both performed by the government. It would invest the net revenue it receives from firms.

\section{Conclusion}

This article has endeavored to show that Austrian School economists are on shaky ground when they claim that they have a calculation case against the use of a decentralized price system in a socialist economy. One can point to problems, but there would certainly be no groping in the dark. The case is even weaker once you consider the ways that such a price system could actually be superior to what we find under capitalism. Hayek's characterization of the problem as being one of practicality is a clear retreat from the claim that it is a matter of logical impossibility. In sum, the debate over social ownership resides exclusively in the realm of motivation and behavior; there is no separate calculation problem.

\section{References}

Batemarco, Robert J. 1994. 'Austrian Business Cycle Theory.' In The Elgar Companion to Austrian Economics, ed. Peter Boettke. Cheltenham, UK: Edward Elgar Publishing.

Boettke, Peter J. 2000. 'Towards a History of the Theory of Socialist Planning.' In Socialism and the Market: The Socialist Calculation Debate Revisited, ed. Peter J. Boettke. London; New York: Routledge.

Cockshott, W Paul, and Allin Cottrell. 1993a. 'Calculation, Complexity and Planning: The Socialist Calculation Debate Once Again.' Review of Political Economy 5 (1): 73-112. 1993b. Towards a New Socialism. Nottingham, England: Spokesman.

Florence, P. Sargant. 1932. 'Review of Robinson (1931).' Economic Journal (March): 66-70.

Hayek, Friedrich A. 1935. 'The Present State of the Debate.' In Collectivist Economic Planning: Critical Studies on the Possibilities of Socialism, ed. F. A. Hayek. London: Routledge and Kegan Paul. Reprinted in Hayek, 1948.

. 1940. 'The Competitive 'Solution." Economica VII (26): 125-49. Reprinted in Hayek, 1948. 1948. Individualism and Economic Order. Chicago, Illinois: The University of Chicago Press. 
Horwitz, Steven. 1996. 'Money, Money Prices, and the Socialist Calculation Debate.' Advances in Austrian Economics 3: 59-77.

Lange, Oskar. 1938. 'On the Economic Theory of Socialism.' In On The Economic Theory of Socialism, ed. B. E. Lippincott. Minneapolis, MN: University of Minnesota Press.

Lavoie, Don. 1985. Rivalry and Central Planning: The Socialist Calculation Debate Reconsidered. Cambridge [Cambridgeshire]; New York: Cambridge University Press.

. 1986. 'Between Institutionalism and Formalism: The Rise and Fall of the Austrian School's Calculation Argument: 1920-1950.'

https://donaldclavoie.files.wordpress.com/2013/11/between20institutionalism20and20forma lism.pdf

1990. 'Computation, Incentives, and Discovery: The Cognitive Function of Markets in Market Socialism.' Annals of the American Academy of Political and Social Science 507 (1): 72-79.

Mises, Ludwig von. [1920] 1935. 'Economic Calculation In The Socialist Commonwealth.' In Collectivist Economic Planning: Critical Studies on the Possibilities of Socialism, ed. Friedrich A Hayek. London: Routledge and Kegan Paul. . [1936] 1951. Socialism, an Economic and Sociological Analysis. New Haven: Yale University Press.

. [1949] 1998. Human Action: A Treatise on Economics. Scholar's ed. Auburn, Ala: Ludwig Von Mises Institute.

Robinson, E. A. G. 1931. The Structure of Competitive Industry (Cambridge Economic Handbooks, Vol. VII). London: Cambridge University Press. 